\title{
IDENTIFIKASI GOLONGAN SENYAWA ANTIOKSIDAN DENGAN MENGGUNAKAN METODE PEREDAMAN RADIKAL DPPH EKSTRAK ETANOL DAUN Cordia myxa L.
}

\author{
Rezki Amriati Syarif ${ }^{1}$, Muhajir, Aktsar Roskiana Ahmad, Abd. Malik \\ Universitas Muslim Indonesia, Jl. Urip Sumiharjo KM 5 \\ Makassar 90132, Indonesia \\ 1amriati.syarif@ymail.com
}

\begin{abstract}
Cordia myxa L .leaf is a plant from Boraginaceae family which is traditionally used as medicine of several skin diseases. The purpose of thid research is to know the chemical compound antioxidant activity of ethanolic extract of Cordia myxa L. leaf. The used extraction method was maceration method using $70 \%$ as solvent. Identification of coumpound group used color reaction and precipitation method respectively. While antioxidant activity test used free radical scavenging method of DPPH (1,1-dyphenyl-2 pycril Hydrazil). From the extraction result, that was found that \%redamen of ethanolic extract of Cordia myxa L .leaf $2.76 \%$. While the determination of chemical compound showed that ethanolic extcract of Cordia myxa L .leaf containing steroid, flavonoid, saponin, and phenol. The result antioxidant activity assay showed that ethanolic extract of Cordia myxa L .leaf has intermediate free antiradical activity with IC So $_{0}$ value 54.92 $\mu \mathrm{g} / \mathrm{mL}$. But it is potensial is lower than Quarcetin which has IC 50 value $0.52 \mu \mathrm{g} / \mathrm{mL}$.
\end{abstract}

Keywords : Antioxidant, ethanolic extract, Cordia myxa L. leaf, DPPH, $\mathrm{IC}_{50}$ value

\section{PENDAHULUAN \\ Latar Belakang}

Kesibukan, polusi, kontaminasi, radiasi (matahari dengan lapisan ozon tipis), kelelahan, stress dan berbagai penyakit yang ditimbulkannya akan berakibat tubuh mengeluarkan oksigen radikal atau radikal bebas yang berlebihan. Radikal bebas menimbulkan banyak masalah kesehatan (Mukarromah, 2010). Suatu radikal bebas ialah atom atau gugus apa pun yang memiliki satu atau lebih elektron tak berpasangan. Ciri umum dari hampir semua radikal bebas ialah kereaktifan kimia yang tinggi yang dikaitkan dengan kecenderungan elektron untuk terdapat sebagai pasangan (Pine, 1988). Dalam bidang medis, diketahui bahwa radikal bebas merupakan biang keladi berbagai keadaan patologis seperti penyakit liver, jantung koroner, kanker, diabetes, katarak, penyakit hati, dan berbagai proses penuaan dini (Sinly, 2008).

Di dalam tubuh kita terdapat senyawa yang dapat menangkal radikal bebas yang disebut antioksidan. Namun pola hidup dan pola makan yang tidak benar serta bertambahnya usia menyebabkan produksi antioksidan dalam tubuh semakin berkurang sehingga kita memerlukan antioksidan dari luar tubuh (Kumalaningsih, 2007).

Antioksidan adalah senyawa yang memiliki struktur molekul yang dapat memberikan elektronnya dengan cuma-cuma kepada molekul radikal bebas tanpa terganggu sama sekali dan dapat memutuskan reaksi berantai dari radikal bebas. Antioksidan banyak kita temukan dalam makanan yang berasal dari tumbuhtumbuhan (Yuliarti, 2008).

Penemuan obat baru dan kebutuhan sediaan obat baru terus meningkat sejalan dengan adanya tuntutan akan perbaikan standar kesehatan manusia dapat diperoleh melalui penggunaan obat yang lebih efektif dan efisien. Salah satu cara yang dapat dilakukan untuk mencapai tujuan tersebut antara lain adalah dengan optimalisasi pemanfaatan tanaman obat yang sudah banyak digunakan dan terbukti secara empiris memberi efek pengobatan. 
Cordia myxa L. memiliki beberapa manfaat dalam pengobatan. Dalam beberapa penelitian Cordia myxa L. telah dilaporkan memiliki efek farmakologi seperti anti tukak lambung, aktivitas hepatoprotective, anti inflamasi, anti diabetes, penyakit degenerativ, anti mikroba, dan berpotensi sebagai antioksidan (Hussain, 2013).

Berdasarkan hal tersebut diatas, maka akan dilakukan penelitian pengujian aktifitas antioksidan dari tumbuhan Cordia myxa L. untuk menambah data ilmiah tumbuhan yang berkhasiat sebagai obat.

\section{METODE PENELITIAN}

\section{A. Pengambilan dan Pengolahan sampel}

Sampel daun Cordia myxa L. diambil di Kab. Enrekang. Daun yang telah diambil kemudian dibersihkan dari kotoran yang melekat dengan menggunakan air mengalir lalu dikeringkan dengan cara diangin-anginkan. Selanjutnya dihaluskan, kemudian siap untuk diekstraksi.

\section{B. Ekstraksi}

Serbuk daun Cordia myxa L. sebanyak $300 \mathrm{~g}$ dimasukkan ke dalam wadah maserasi, lalu ditambahkan pelarut etanol sebanyak $2000 \mathrm{~mL}$ hingga simplisia tersebut terendam, dibiarkan selama 3 hari dalam bejana tertutup dan terlindung dari cahaya matahari langsung sambil diaduk secara periodik, setelah 3 x 24 jam dilakukan penyaringan dan ampasnya dimaserasi kembali dengan cairan penyari yang baru. Maserasi dilakukan sebanyak 3 kali dan diperoleh ekstrak metanol cair. Hasil penyarian yang diperoleh kemudian diuapkan dengan menggunakan rotavapor sehingga akan diperoleh ekstrak kental.

\section{Pengujian Fitokimia}

Uji fitokimia dilakukan untuk mengetahui ada tidaknya komponenkomponen bioaktif yang terdapat pada ekstrak metanol daun Cordia myxa L. yang memiliki aktivitas antioksidan tertinggi. Uji fitokimia meliputi uji alkaloid, uji steroid/triterpenoid, flavonoid, saponin, fenol hidrokuinon.

\section{a. Steroid/ triterpenoid}

Sejumlah sampel dilarutkan dalam $2 \mathrm{ml}$ kloroform dalam tabung reaksi yang kering. Lalu, ke dalamnya ditambahkan 10 tetes anhidra asetat dan 3 tetes asam sulfat pekat. Terbentuknya larutan berwarna merah untuk pertama kali kemudian berubah menjadi biru dan hijau menunjukkan reaksi positif (Harborne, 1984).

b. Flavonoid

Sari 0,5 g serbuk yang diperiksa atau sisa kering $10 \mathrm{~mL}$ sediaan berbentuk cairan, dengan $10 \mathrm{~mL}$ metanol $\mathrm{P}$, menggunakan alat pendingin balik selama 10 menit. Saring panas melalui kertas saring kecil berlipat, encerkan filtrat dengan $10 \mathrm{~mL}$ air. Setelah dingin tambahkan $5 \mathrm{~mL}$ eter minyak tanah $\mathrm{P}$, kocok hati-hati diamkan. Ambil lapisan metanol, uapkan pada suhu $40^{\circ}$ dibawah tekanan. Sisa dilarutkan dalam $5 \mathrm{~mL}$ etil asetat $\mathrm{P}$, saring. Kemudian, uapkan hingga kering $1 \mathrm{~mL}$ larutan percobaan, basahkan sisa dengan aseton $\mathrm{P}$, tambahkan sedikit serbuk halus asam borat $\mathrm{P}$ dan serbuk halus oksalat $\mathrm{P}$, panaskan hati-hati diatas tangas air dan hindari pemanasan yang berlebihan. Campur sisa yang diperoleh dengan $10 \mathrm{~mL}$ eter P. Amati dengan sinar UV $366 \mathrm{~nm}$, larutan berfluorosensi kuning intensif, menunjukkan adanya flavonoid (Departemen Kesehatan RI, 1978).

c. Saponin / Uji busa

Saponin dapat dideteksi denan uji busa dalam air panas. Busa yang stabil selama 30 menit dan tidak hilang pada penambahan 1 tetes $\mathrm{HCl} 2 \mathrm{~N}$ menunjukkan adanya saponin (Harborne, 1984).

d. Fenol

Sebanyak 1 gram sampel diekstrak dengan $20 \mathrm{ml}$ etanol $70 \%$. Larutan yang dihasilkan diambil sebanyak $1 \mathrm{ml}$ kemudian ditambahkan 2 tetes larutan $\mathrm{FeCl}_{3} 5 \%$. Terbentuknya warna hijau atau hijau biru menunjukkan adanya senyawa fenol dalam bahan (Harborne, 1984).

e. Alkaloid

Ekstrak etanol 70\% dimasukkan kedalam masing-masing tabung reaksi kemudian ditetesi (Harborne, 1984)

1. $\mathrm{HCl} 0,5 \mathrm{~N}$ dan pereaksi Mayer, jika mengandung alkaloid maka akan menghasilkan endapan kuning.

2. $\mathrm{HCl} 0,5 \mathrm{~N}$ dan pereaksi Bauchardat, jika mengandung alkaloid maka akan menghasilkan endapan coklat. 
3. $\mathrm{HCl} 0,5 \mathrm{~N}$ dan pereaksi Dragendrof, jika mengandung alkaloid akan menghasilkan endapan jingga.

\section{Uji Aktivitas Antioksidan}

Pengujian aktivitas antioksidan dengan metode peredaman radikal DPPH merujuk pada prosedur Brand William, et. al., (1995) dan Ahmad, et. al., (2012).

a. Uji Pendahuluan

Ekstrak metanol daun Cordia myxa L. ditotolkan pada lempeng KLT kemudian dielusi dengan menggunakan eluen Heksan:Etil Asetat (3:7). Lempeng KLT disemprot dengan menggunakan 1,1Diphenyl-2-Picryl Hydrazil (DPPH) dan dibiarkan mengering hingga terjadi perubahan dari warna ungu ke kuning.

b. Penentuan Panjang Gelombang

Maksimal

Penentuan panjang gelombang maksimum terhadap larutan DPPH dilakukan dengan cara mengukur pada panjang gelombang 400-700 nm, kemudian dari hasil pengukuran ditentukan panjang gelombang maksimumnya.

c. Pembuatan Larutan DPPH

Larutan DPPH dibuat dengan cara menimbang DPPH sebanyak $5 \mathrm{mg}$, kemudian dilarutkan dengan menggunakan $100 \mathrm{~mL}$ pelarut metanol p.a (50 ppm).

d. Pembuatan Larutan Sampel

Dibuat larutan stok 500 ppm dengan cara menimbang ekstrak metanol daun Cordia myxa L. sebanyak $12,5 \mathrm{mg}$ dan dilarutkan dengan metanol p.a sambil diaduk dan dihomogenkan lalu cukupkan volumenya hingga $25 \mathrm{~mL}$. selanjutnya dilakukan pengenceran :

1. Masing-masing larutan stok dipipet 0,1 mL kemudian dicukupkan dengan metanol p.a sampai volume akhir 5 $\mathrm{mL}(10 \mathrm{ppm})$.

2. Masing-masing larutan stok dipipet 0,2 mL kemudian dicukupkan dengan metanol p.a sampai volume akhir 5 $\mathrm{mL}$ (20 ppm).

3. Masing-masing larutan stok dipipet 0,5 mL kemudian dicukupkan dengan metanol p.a sampai volume akhir 5 $\mathrm{mL}$ (50 ppm).
4. Masing-masing larutan stok dipipet 0,75 mL kemudian dicukupkan dengan metanol p.a sampai volume akhir $5 \mathrm{~mL}$ (75 ppm).

5. Masing-masing larutan stok dipipet 1,0 mL kemudian dicukupkan dengan metanol p.a sampai volume akhir 5 $\mathrm{mL}$ (100 ppm).

6. Masing-masing larutan stok dipipet 1,5 mL kemudian dicukupkan dengan metanol p.a sampai volume akhir 5 $\mathrm{mL}$ (150 ppm).

e. Pembuatan Larutan Pembanding

Dibuat larutan stok 50 ppm dengan cara menimbang kuersetin setara $5 \mathrm{mg}$ dan dilarutkan dengan metanol p.a sambil diaduk dan dihomogenkan lalu cukupkan volumenya hingga $100 \mathrm{~mL}$, kemudian dilakukan pengenceran :

1. Masing-masing larutan stok dipipet 0,2 mL kemudian dicukupkan dengan metanol p.a sampai volume akhir 5 $\mathrm{mL}$ (2 ppm).

2. Masing-masing larutan stok dipipet 0,4 mL kemudian dicukupkan dengan metanol p.a sampai volume akhir 5 $\mathrm{mL}$ (4 ppm).

3. Masing-masing larutan stok dipipet 0,6 mL kemudian dicukupkan dengan metanol p.a sampai volume akhir 5 $\mathrm{mL}$ (6 ppm).

4. Masing-masing larutan stok dipipet 0,8 mL kemudian dicukupkan dengan metanol p.a sampai volume akhir 5 $\mathrm{mL}$ (8 ppm).

f. Pengukuran Blangko

Larutan DPPH sebanyak 3,5 mL ditambahkan metanol pa $0.5 \mathrm{~mL}$, kemudian di inkubasi pada suhu $37^{\circ} \mathrm{C}$ selama 30 menit, selanjutnya diukur serapannya pada panjang gelombang maksimum (Ahmad, et. al., 2012).

g. Pengukuran Aktivitas Antioksidan sampel

Pengujian dilakukan dengan memipet $500 \mu \mathrm{L}$ larutan sampel dari berbagai konsentrasi. Kemudian masing-masing ditambahkan 3,5 mL DPPH 50 ppm dan dicukupkan volumenya dengan metanol p.a sampai 4,0 mL dalam labu tentukur. Campuran kemudian disonikasi dan diinkubasi selama 30 menit pada suhu $37^{\circ} \mathrm{C}$, lalu serapannya diukur pada panjang gelombang maksimal (Ahmad, et. al., 2012). 
h. Penghitungan nilai $\mathrm{IC}_{50}$

Nilai $\mathrm{IC}_{50}$ dihitung menggunakan persamaan regresi. Larutan sampel 0,1 $\mathrm{mL}$ ditambahkan dengan 3,5 $\mathrm{mL}$ larutan DPPH, dikocok hingga homogen, diinkubasi pada suhu $37^{\circ} \mathrm{C}$ selama 30 menit dan diukur serapannya pada panjang gelombang $517 \mathrm{~nm}$. Perlakuan yang sama dilakukan pada kuarsetin sebagai baku pembanding. Persentase peredaman radikal DPPH dihitung dengan persamaan (Ahmad,et al., 2012) :

$$
\% \text { peredaman }=\frac{(A-\mathbb{I})}{A} \times 100 \%
$$

Dimana: $\mathrm{A}=$ Nilai serapan blangko

$$
\text { B = Nilai serapan sampel }
$$

III. Hasil Dan Pembahasan

Tabel 1. Persen rendamen

\begin{tabular}{cccc}
\hline Pelarut & $\begin{array}{c}\text { Berat } \\
\text { sampel } \\
\text { kering } \\
(\mathrm{g})\end{array}$ & $\begin{array}{c}\text { Berat } \\
\text { ekstrak } \\
(\mathrm{g})\end{array}$ & $\begin{array}{c}\text { Rendamen } \\
(\%)\end{array}$ \\
\hline Metanol & 300 & 8,29 & 2,76 \\
\hline
\end{tabular}

Tabel 2. Hasil pengukuran absorbansi, persen inhibisi, dan nilai $\mathrm{IC}_{50}$ ekstrak etanol daun Cordia myxa L dan pembanding kuarsetin

\begin{tabular}{ccccc}
\hline Sampel & $\begin{array}{c}\text { Konsentrasi } \\
(\mathrm{ppm})\end{array}$ & Absorbansi & \% inhibisi & $\begin{array}{c}\mathrm{IC}_{50} \\
(\mathrm{~g} / \mathrm{mL})\end{array}$ \\
\hline Blanko DPPH & 50 & 1,411 & - & - \\
\hline & & & & \\
ekstrak etanol & 10 & 0,965 & 31,60 & \\
daun Cordia & 20 & 0,950 & 32,67 & 54,92 \\
myxa L. & 50 & 0,914 & 35,22 & \\
& 75 & 0,904 & 35,93 & \\
& 100 & 0,890 & 36,92 & \\
& 150 & 0,885 & 37,27 & \\
& & & & \\
& 2 & & & \\
kuarsetin & 4 & 0,762 & 45,99 & \\
& 6 & 0,727 & 48,47 & 53,93 \\
\end{tabular}

\begin{tabular}{|c|c|}
\hline Pengujian & Keterangan \\
\hline Steroid & + \\
\hline Flavonoid & + \\
\hline Saponin & + \\
\hline Fenol hidrokuinon & + \\
\hline Alkaloid & + \\
\hline \multicolumn{2}{|c|}{ Keterangan : $+=$ ada $;-=$ tidak ada } \\
\hline $\begin{array}{l}\text { Antioksidan } \\
\text { yang berguna menga } \\
\text { akibat radikal bebas }\end{array}$ & $\begin{array}{l}\text { pakan seny } \\
\text { rusakan oksi } \\
\text { tubuh sehil }\end{array}$ \\
\hline
\end{tabular}

Tabel 3. Hasil penapisan fitokimia berperan mencegah berbagai macam penyakit. Penelitian ini menggunakan daun Cordia myxa L. untuk memberikan data secara ilmiah dan metode ekstraksi yang digunakan adalah metode maserasi yang merupakan salah satu metode ekstraksi dingin. Metode ini tidak merusak komponen kimia daun Cordia myxa L. karena tidak adanya pemanasan dalam proses ekstraksi. Proses ekstraksi dilakukan menggunakan cairan penyari etanol $70 \%$. Dimana pelarut ini dipilih karena memiliki kemampuan untuk menarik senyawa polar dan beberapa senyawa nonpolar. 
Ekstrak daun Cordia myxa L. yang diperoleh dari maserasi menggunakan pelarut etanol $70 \%$ diuji komponen bioaktifnya menggunakan metode fitokimia. Pengujian ini akan menghasilkan komponen bioaktif apa saja yang terdapat pada pelarut tersebut. Uji fitokimia dipilih karena dapat mendeteksi komponen bioaktif yang tidak terbatas hanya pada metabolit sekunder saja, tetapi juga terhadap metabolit primer yang memberikan aktivitas biologis fungsional, seperti protein dan peptide (Apriandi, 2011).

Dari hasil ekstraksi diperoleh persen rendamen ekstrak etanol daun Cordia myxa L sebesar 2,76\% yang diekstrasi dengan $2 \mathrm{~L}$ pelarut.

Uji fitokimia yang dilakukan pada penelitian ini, meliputi uji flavonoid, saponin, fenol, terpen dan steroid. Adapun hasil uji fitokimia dari hasil penelitian menunjukkan bahwa ekstrak etanol daun Cordia myxa L mengandung saponin, flavonoid, fenol, dan steroid.

Kemudian ekstrak yang peroleh dilakukan pengujian aktivitas antiradikal bebas dengan menggunakan DPPH. Metode DPPH dipilih karena sederhana, mudah, cepat dan peka serta hanya memerlukan sedikit sampel. Senyawa antioksidan akan bereaksi dengan radikal DPPH melalui mekanisme donasi atom hidrogen dan menyebabkan terjadinya peluruhan warna dari ungu ke kuning (Blois, 1958 diacu pada Endang hanani 2005).

Pelarut yang digunakan untuk melarutkan DPPH dan sampel adalah metanol dikarenakan metanol tidak mempengaruhi dalam reaksi antara sampel uji sebagai antioksidan dengan DPPH sebagai radikal bebas (Molyneux, 2004).

Pada penelitian ini pengerjaannya merujuk pada prosedur Brand-Williams, et. al., 1995 dengan beberapa modifikasi. Dimana pengukuran absorbansi sampel pada spektro UV-Vis dengan panjang gelombang 517 dengan volume sampel yang digunakan adalah $0,5 \mathrm{~mL}$ dan DPPH adalah 3,5 mL. Dimana konsentrasi sampel yang digunakan adalah 10, 20, 50, 75, 100 dan 150 ppm sedangkan konsentrasi pembanding adalah 2, 4, 6, 8 ppm. Dimana pembanding yang digunakan sebagai kontrol positif adalah kuersetin.

Perhitungan persen inhibisi dan $\mathrm{IC}_{50}$ dari antiradikal bebas dari masing- masing ekstrak etanol daun Cordia myxa dan kuersetin dilakukan. Persen inhibisi adalah kemampuan suatu bahan untuk menghambat aktivitas radikal bebas yang berhubungan dengan konsentrasi suatu sampel. Sedangkan nilai $\mathrm{IC}_{50}$ sendiri merupakan salah satu parameter yang biasa digunakan untuk menginterpretasikan hasil dari pengujian DPPH, makin rendah nilai $\mathrm{IC}_{50}$ dari suatu sampel maka kemampuannya sebagai antioksidan semakin besar.

Menurut Phongpaichit, et. al., (2007), suatu senyawa dikatakan sebagai antiradikal bebas sangat kuat apabila nilai $\mathrm{IC}_{50}<10 \mathrm{~g} / \mathrm{mL}$, kuat apabila nilai $\mathrm{IC}_{50}$ antara $10-50 \mathrm{~g} / \mathrm{mL}$, sedang apabila nilai $\mathrm{IC}_{50}$ berkisar antara $50-100 \mathrm{~g} / \mathrm{mL}$, lemah apabila nilai $\mathrm{IC}_{50}$ berkisar antara 100-250 $\mathrm{g} / \mathrm{mL}$ dan tidak aktif apabila $\mathrm{IC}_{50}$ diatas 250 $\mathrm{g} / \mathrm{mL}$.

Pada penelitian ini, nilai $\mathrm{IC}_{50}$ kuersetin yang diperoleh sebesar 0,522 $\mathrm{g} / \mathrm{mL}$, ini menunjukkan bahwa antioksidan kuersetin merupakan antioksidan dengan aktivitas yang sangat kuat $(<10 \mathrm{~g} / \mathrm{mL})$. Sedangkan ekstrak etanol daun Cordia myxa memiliki aktivitas antiradikal bebas sedang dengan nilai $\mathrm{IC}_{50} 54,92 \mathrm{~g} / \mathrm{mL}$.

Berdasarkan hasil penelitian ini senyawa yang memiliki potensi sebagai antioksidan pada ekstrak etanol daun Cordia myxa L adalah saponin dan flavanoid. Dimana saponin mampu meredam superoksida melalui pembentukan intermediet hidroperoksida sehingga mencegah kerusakan biomolekular oleh radikal bebas (Ali, et. al., 2012). Sedangkan flavonoid yang merupakan senyawa polifenol mempunyai kemampuan untuk menyumbangkan atom hidrogen kepada senyawa radikal bebas, maka aktivitas antioksidan senyawa polifenol dapat dihasilkan pada reaksi netralisasi radikal bebas atau pada penghentian reaksil berantai yang terjadi (Yuhernita dan Juniarti, 2011).

Flavonoid adalah senyawa polifenol (mengandung beberapa gugus hidroksil fenolik) dan beberapa senyawa lainnya. Sifat kimia inilah yang mendasari banyaknya efek farmakologi secara in vitro yang berkesan dari senyawa ini. Khususnya, flavanoid mampu untuk mengkompleks dengan ion logam, bekerja sebagai antioksidan dan berikatan dengan protein seperti enzim dan protein struktural 
(keistimewaan terakhir inilah yang dapat juga menjelaskan kemampuan dari flavonoid untuk meningkatkan kemampuan dari jaringan konektif).

Sifat antioksidan dari flavonoid secara in vitro telah menjadi fokus utama dari kebanyakan penelitian selama akhirakhir ini. Kemampuan dari flavonoid untuk mengkompleks dengan ion logam seperti besi yang memungkinkan menambah efek antioksidannya pada keadaan khusus ini. Yang paling khusus adalah kemampuan dari flavonoid untuk menghambat oksidasi yang dibantu oleh makrofag dari LDL dengan demikian menunjang atherogenesis. Sifat antioksidan dari flavonoid dapat juga menunjang efek antiinflamasi dan antiplatelet dan dikaitkan bukan hanya dari sifat strukturnya tapi juga kemampuaanyya untuk berinteraksi dan berpenetrasi dengan lapisan lipid dari membrane sel. Flavonoid meredam radikal nitrit oksida, anion superoksida, dan oksigen singlet. Seperti kebanyakan antioksidan lainnya, flavonoid juga dapat bekerja seperti prooksidan pada keadaan tertentu (Mills dan Bone, 2000).

\section{KESIMPULAN}

Berdasarkan hasil penelitian yang dilakukan dapat disimpulkan bahwa, daun Cordia myxa L. memiliki potensi sebagai antioksidan dengan nilai $\mathrm{IC}_{50}$ ekstrak metanol 54,92 g/mL dengan Kandungan kimia adalah fenol, steroid, flavonoid dan saponin.

\section{DAFTAR PUSTAKA}

1. Agoes, Goeswin, 2007. Teknologi Bahan Alam. Institut Teknologi Bandung, Bandung.

2. Ahmad, A. R., et al., 2012. Study of antioxidant activity with reduction of free radical DPPH and xanthine oxidase inhibitor of the extract Ruellia tuberosa Linn Leaf. International Research Journal of Pharmacy, 3 : (2729).

3. Apriandi, A. 2011. Aktivitas Antioksidan dan Komponen Bioaktif Keong Ipon-ipong (Fasciolaria salmo).
4. Blois, MS. 1958. Antioksidant determination by the use of a stable free radikal. Nature 181. 1199-1200

5. Brand, Williams., 1995. Use of a Free Radical Method to Evaluate Antioxidant Activity. Lebensmittel Wissens Chaftund Technology. Germany.

6. Direktorat Jenderal Pengawasan Obat dan Makanan, 1978. Material Medika Indonesia Jilid V. Jakarta : Departemen Kesehatan RI.

7. Direktorat Jenderal Pengawasan Obat dan Makanan, 1986. Sediaan Galenik. Departemen Kesehatan RI, Jakarta.

8. Fessenden. J Ralf, dkk., 1986. Kimia Organik Edisi III. Glora Aksara Pratama. Jakarta

9. Halliwell B. 1999., Free Radicals in Biology and Medicine. Third ed. Clarendon Press. Oxford. England

10. Harborne, J.B., 1980. Metode Fitokimia, Penuntun Cara Modern Menganalisa Tumbuhan. Terjemahan K. Padmawinata. Bandung : ITB.

11. Hernani, 2005. Tanaman Berkhasiat Antioksidan. Jakarta : Penerbit Swadya.

12. Hussain, N., 2013. Ethnobotany and Phytopharmacology of Cordya Dichotoma. Department of pharmaceutical Science. Dibrugarh University. India.

13. Integrated Taxonomic Information System. 2012. Cordia myxa L (Online). (http://www.itis.gov/servlet/SingleRpt/S ingleRpt. Diakses tanggal $26 \mathrm{Mei}$ 2013).

14. Kumalaningsih, S., 2006. Antioksidan Alami. Trubus Angrisarana. Surabaya

15. Lembaga Ilmu Pengetahuan dan Informasi, 2011. Hasil Identifikasi/Determinasi Tumbuhan Cordia myxa L. Pusat Penelitian Biologi, Bogor. 
16. Mills \& Bone, 2000. Principles and Practice of Phytoterapy. 90 Tottenham Court Road. London.

17. Mukarromah, Baitul, 2010. Dampak Radikal Bebas dan Antioksidan Terhadap Kesehatan Tubuh, (Online). http://blog.unnes.ac.id/sitibaitul/archive s/33.com (Diakses 03 Januari 2012).

18. Molyneux, P., 2004, Use of DPPH to Estimate antioxidant Activity. Journal Science Tecnology. 26 (2).

19. Phongpaichit, S., Nikom, J., Rungjindamai, N., Sakayaroj, J., Hutadilok-Towatana, N., Rukachaisirikul, V., Kirtikara, K. (2007). Biological Activities of Extracts From Endophytic Fungi Isolated From Garcinia Plants. Immunology \& Medical Microbiology, 51, 517-52.

20. Pine, Stanley H. 1988. Kimia Organik 2.Penerbit ITB, Bandung.

21. Sinly. 2008. Antioksidan Alami Di Sekitar Kita (Online). http://www.chem-is try.org/artikel_kimia/kimia_pangan/anti oksidan-alami-di-sekitar-kita.com

(Diakses tanggal 08 Oktober 2012).

22. Voight, Rudolf, 1995. Buku Pelajaran Teknologi Farmasi. Gadjah Mada University Press, Yogyakarta.

23. Winarsi, Hery, 2007. Antioksidan Alami dan Radikal bebas. Kanisius, Yogyakarta.

24. Yuhernita \& Juniarti. 2011. Analisis senyawa Metabolit Sekunder Dari Ekstrak Metanol Daun Surian yang Berpotensi Sebagai Antioksidan. Jakarta 10510

25. Yuliarti, Nurheti, 2008. Racun di Sekitar Kita. Penerbit ANDI, Yogyakarta. 